\title{
PRAVO NA NAKNADU ŠTETE ZBOG NEOPRAVDANE OSUDE ILI NEUTEMELJENOG UHIĆENJA ILI PRITVARANJA, S NAGLASKOM NA UPRAVNO POSTUPANJE U OSTVARIVANJU TOGA PRAVA
}

Sažetak: $\quad$ Nakon konstatacije, u uvodu, da je pravo na naknadu štete zbog neopravdane osude ili neutemeljenog uhićenja kao ljudsko pravo zajamčeno međunarodnim dokumentima i Ustavom Republike Hrvatske, a ostvarivanje toga prava uređeno posebnim zakonskim propisima, u radu se razmatra prije sudbene obvezna upravna faza postupka za naknadu štete u kontekstu konvencijskog prava. Analiziraju se odluke Europskog suda za ljudska prava kako bi se dobio odgovor na pitanje krši li hrvatsko pravo na taj način "pravo na pristup sudu" zajamčeno člankom 6. stavkom 1. Europske konvencije za zaštitu ljudskih prava i temeljnih sloboda. Nastavlja se izlaganjem o pravnoj osnovi odgovornosti za štetu zbog neopravdane osude ili neutemeljenog uhićenja, a zatim obradom prava na naknadu štete u međunarodnim dokumentima i praksi Europskog suda za ljudska prava te u domaćem pravu. Slijede podaci iz hrvatske prakse upravnog stadija ostvarivanja prava na naknadu štete te na kraju zaključci u kojima se iznose ključni rezultati rada.

Ključne riječi: $\quad$ Europski sud za ljudska prava, neopravdana osuda, neutemeljeno uhićenje ili pritvaranje, naknada štete

Dr. sc. Boris Ljubanović, redoviti profesor, Pravni fakultet Sveučilišta Josipa Jurja Strossmayera u Osijeku, Stjepana Radića 13, Osijek. Adresa e-pošte: ljboris@pravos.hr. ORCID: https://orcid org /0000-0003-3995-9991. 


\section{UVOD}

Pravo na naknadu štete zbog neopravdane osude ili neutemeljenog uhićenja zajamčeno je međunarodnim pravom o ljudskim pravima i slobodama te odredbom članka 25. stavka 4. Ustava Republike Hrvatske (dalje: URH). ${ }^{1}$ Ostvarivanje tog ustavnog prava normirano je posebnim zakonskim propisima. Riječ je o ustupanju ustavnog prava zakonskom reguliranju koje je u Njemačkoj ustavnopravnoj teoriji poznato pod nazivom "zakonski pridržaj (ograničenje)" (Vorbehalt des Gesetzes). ${ }^{2}$

Zakonski propisi o pravu na naknadu štete ${ }^{3}$ bili su predviđeni Zakonikom o krivičnom postupku iz 1953. bivše Jugoslavije i to njegovom novelom iz 1965. (priznato je pravo na naknadu štete zbog neopravdane osude i za nezakoniti (ne i neutemeljeni - B. Lj.) pritvor te Ustavom iz 1963. te države (on je u članku 50. stavku 6. propisao da svatko tko je bio neopravdano osuđen ili nezakonito pritvoren ima pravo na naknadu štete iz društvenih sredstava). Savezni Ustav iz 1974. proširio je to pravo jer je u odredbi članka 181. stavka 5. predvidio da pravo na naknadu štete iz društvenih sredstava i druga prava utvrđena zakonom pripadaju osobi koja je neopravdano osuđena ili neutemeljeno lišena slobode.

U odredbi članka 25. stavka 4. URH određeno je da "svatko tko je bio nezakonito lišen slobode ili osuđen ima, u skladu sa zakonom, pravo na odštetu i javnu ispriku.”

Važeći Zakon o kaznenom postupku iz 2008., s kasnijim novelama, ${ }^{4}$ ne sadrži propise o naknadi štete zbog neopravdane osude ili neutemeljenog uhićenja jer je prihvaćeno shvaćanje da je riječ o materiji koju treba normirati posebnim zakonom. Stoga je on propisao, u odredbi članka 573., da će se Glava XXX. (naslov joj je Postupak za naknadu štete i ostvarivanje drugih prava neopravdano osuđenih ili neutemeljeno uhićenih osoba) Zakona o kaznenom postupku iz 1997., s naknadnim izmjenama i dopunama, ${ }^{5}$ primjenjivati do donošenja posebnog zakona. Te odredbe predstavljaju lex specialis u odnosu na opće odredbe našeg odštetnog prava. ${ }^{6}$

1 Ustav Republike Hrvatske (Narodne novine, broj 56/1990, 135/1997, 8/1998 - pročišćeni tekst, 113/2000, 124/2000 pročišćeni tekst, 28/2001, 41/2001 - pročišćeni tekst, 55/2001, 76/2010, 85/2010, 5/2014).

2 Usp. Creifelds, Rechtswörtherbuch, 17. Auflage, Verlag C. H. Beck, München, 2002., str. 584.

3 Pravo na naknadu štete bilo je predviđeno austrijskim Zakonom iz 1892. godine te zakonskom odredbom iz 1918. godine koji su vrijedili u Dalmaciji, ali ne u kontinentalnoj Hrvatskoj. Ona je imala svoj Zakon o kaznenom postupku iz 1875. godine koji pravo na naknadu štete nije propisao. Za povijesni pregled naknade štete za neopravdano lišenje slobode vidjeti Vesel, J., Naknada za nepravedno određen pritvor i istražni zatvor, Posebni otisak koreferata za II. Kongres pravnika Kraljevine S.H.S. održanog u Ljubljani od 9.-11. septembra 1926., Ljubljana, 1927., str. 6.-7.

4 Zakon o kaznenom postupku (Narodne novine, broj 152/2008, 76/2009, 80/2011,143/2012, 56/2013, 145/2013, 152/2014, 70/2017).

5 Članci koje u nastavku teksta navodimo bez oznake zakona odnose se na Zakon o kaznenom postupku iz 1997. (Narodne novine, broj 10/1997, 27/1998, 58/1999, 112/1999, 58/2002, 143/2002, 115/2006).

6 Prema čl. 250. st. 1. Prekršajnog zakona (Narodne novine, broj 107/2007, 39/2013, 157/2013, 110/2015, 91/2016), ako tim Zakonom nije nešto drukčije određeno, u postupku za naknade štete i ostvarivanje drugih prava neopravdano osuđenih i neutemeljeno uhićenih osoba u prekršajnom postupku odgovarajuće se primjenjuju odredbe Zakona o kaznenom postupku. Prema čl. 9. Zakona o izvršavanju kazne zatvora (Narodne novine, broj 190/2003 - pročišćeni tekst, 76/2007, 27/2008, 83/2009, 18/2011, 48/2011, 125/2011, 56/2013, 150/2013) zatvorenik koji je bio žrtva zabranjenih postupaka ima pravo na naknadu štete. Zabranjeni su i kažnjivi postupci kojima se zatvorenika podvrgava bilo kakvom obliku mučenja, zlostavljanja ili ponižavanja te liječničkim ili znanstvenim pokusima, među kojima se poglavito smatraju postupci koji su nerazmjerni održavanju reda i stege u kaznionicama i zatvorima ili su nezakoniti pa mogu proizvesti trpljenje ili neprimjereno ograničenje temeljnih prava zatvorenika. 
Navedenim posebnim propisima treba pridodati i one prema kojima je Republika Hrvatska odgovorna za štetu koju a) stranci u postupku nanese sudac svojim nezakonitim ili nepravilnim radom u obnašanju sudačke dužnosti (čl. 105. st. 1. Zakona o sudovima, Narodne novine, broj 28/2013, 33/2015, 82/2015, 82/2016), b) građaninu ili pravnoj osobi u obnašanju dužnosti nanese državni odvjetnik ili zamjenik državnog odvjetnika nepravilnim ili nezakonitim radom (čl. 128. st. 1. Zakona o državnom odvjetništvu, Narodne novine, broj 76/2009, 153/2009, 116/2010, 145/2010, 57/2011, 130/2011, 72/2013, 148/2013, 33/2015, 82/2015).

\section{OBVEZNI UPRAVNI STADIJ POSTUPKA ZA NAKNADU ŠTETE U KONTEKSTU KONVENCIJSKOG PRAVA NA PRISTUP SUDU}

Postupak za naknadu štete prema domaćem je pravu upravno-sudbeni. Odredbama članka 477. stavka 2. i članka 478. stavka 1. propisana je dužnost oštećenika da se prije podloženja tužbe sudu obrati svojim zahtjevom Ministarstvu pravosuđa radi postignuća nagodbe o postojanju štete te vrsti i visini naknade. Ako taj zahtjev ne bude prihvaćen ili o njemu ne bude odlučeno u roku od tri mjeseca od podnošenja zahtjeva, oštećenik može kod nadležnoga suda podnijeti tužbu za naknadu štete. Ako je nagodba postignuta samo u dijelu zahtjeva, oštećenik može tužbu podnijeti glede ostatka zahtjeva.

Europska konvencija za zaštitu ljudskih prava i temeljnih sloboda (dalje: Konvencija), ${ }^{7}$ koju je Republika Hrvatska ratificirala u studenom 1997., člankom 6. stavkom 1. jamči pravo na pošteno suđenje (fair trial). To pravo obuhvaća niz postupovnih prava među kojima je i ono da "svatko ima pravo da zakonom ustanovljeni neovisni i nepristrani sud (tribunal) (...) ispita njegov slučaj." Riječ je o "pravu na sud" (right to a court) iz kojeg je Europski sud za ljudska prava (dalje: Europski sud) svojim tumačenjem izveo drugo pravo koje Konvencijom izrijekom nije utvrđeno - "pravo na pristup sudu" (right to access to a court). Prema tumačenju Europskog suda kao implicirano pravo (implied right) to je pravo jedan od čimbenika ili vidova "prava na sud", a time i prava na pošteno suđenje.

Primjerice, u presudi Kreuz protiv Poljske (2001.) $)^{8}$ Europski sud iznosi:

“52. Sud ponavlja, kao što je smatrao u mnogim prilikama, da članak 6. stavak 1. svakome osigurava pravo podnijeti bilo koji zahtjev u vezi s njegovim pravima i obvezama građanske naravi pred sud ili sudište (tribunal). Na taj je način u ovu odredbu ugrađeno 'pravo na sud', kojemu je pravo pokrenuti postupak pred sudom u građanskoj stvari samo jedan vid; međutim, taj vid zapravo omogućuje korist od drugih jamstava navedenih u stavku 1. članka 6. Poštenost, javnost i brzina sudskog postupka obilježja su koja nemaju nikakvu vrijednost ako takav postupak prije toga nije uopće pokrenut. Vladavina prava u građanskim stvarima teško se može zamisliti bez postojanja mogućnosti pristupa sudovima (...)."

7 Konvencija za zaštitu ljudskih prava i temeljnih sloboda (Narodne novine - Međunarodni ugovori, broj 18/1997, 6/1999 pročišćeni tekst, 8/1999, 14/2002, 1/2006).

8 Kreuz protiv Poljske, presuda, 28249/95, 19. lipnja 2001. (v. Jasna Omejec, Konvencija za zaštitu ljudskih prava i temeljnih sloboda u praksi Europskog suda za ljudska prava, Strasbourški acquis, Novi informator, Zagreb, 2013., str. 1129., 1131.). 
S obzirom na izloženo, postavlja se pitanje je li hrvatsko pravo, propisivanjem obveznog upravnog postupka za naknadu štete prije sudbenog postupka, krši implicirano konvencijsko "pravo na pristup sudu"? To više jer je Europski sud u predmetu De Geouffre de la Pradelle protiv Francuske (1992.) naglasio kako "način vođenja vrlo složenih upravnih postupaka koje utječu na odlučivanje o građanskim pravima može sam po sebi predstavljati povredu prava na pristup sudu zajamčenog člankom 6. stavkom 1. Konvencije."

U nalaženju odgovora na spomenuto pitanje treba poći od činjenice da je Europski sud u presudama razradio svoje stajalište ne samo o već spomenutim impliciranim pravima (implied rights), nego i o impliciranim ograničenjima (implied limitations).

Opće kriterije impliciranog ograničenja prava na pristup sudu Europski sud je izložio u presudi Ashingdane protiv Ujedinjenog Kraljevstva $(1985 .)^{10}$

“57. (...) pravo na pristup sudovima (...) može podlijegati ograničenjima; ona su implicitno dopuštena jer pravo pristupa 'zahtijeva da bude regulirano od države, što može varirati u pogledu vremena i mjesta ovisno o potrebama i resursima zajednice i pojedinca' (vidjeti presudu Golder ${ }^{11}$ ). Države ugovornice pri donošenju takvih propisa uživaju određeno područje slobodne prosudbe. Iako konačna odluka o pitanju poštovanja Konvencije počiva na Sudu, nije uloga Suda da zamijeni domaće vlasti u procjenjivanju onoga što je najbolja politika u ovom području (...).

No ipak, primijenjena ograničenja ne smiju ograničiti (restrict) ili smanjiti (reduce) pristup ostavljen pojedincu na takav način ili do te mjere da bude narušena sama bit (the very essence) prava. Nadalje, ograničenje neće biti suglasno s člankom 6 . stavkom 1. (...) ako ne teži legitimnom cilju i ako ne postoji razuman odnos razmjernosti (reasonable relationship of proportionality) između primijenjenih sredstava i cilja koji se nastojao postići."

Postavke dopuštenih ograničenja prava na pristup sudu Europski sud nastavio je primjenjivati u već spomenutoj presudi Kreuz protiv Poljske (2001.). ${ }^{12}$

“53. 'Pravo na sud' nije apsolutno. Ono može biti podložno implicitno dopuštenim ograničenjima jer pravo na pristup po samoj svojoj naravi zahtijeva regulaciju države. Jamčeći parničarima učinkovito pravo pristupa sudu radi utvrđivanja njihovih 'prava i obveza građanske naravi', članak 6. stavak 1. ostavlja državi slobodan izbor načina na koji će postići taj cilj, ali dok države ugovornice uživaju određenu slobodu prosudbe u tom smislu, konačna odluka u pogledu poštovanja zahtjeva Konvencije leži na Sudu (...).

55. U tom kontekstu Sud naglašava da postavljeno ograničenje pristupa sudu ili tribunalu neće biti suglasno članku 6. stavku 1., osim ako ne teži legitimnom cilju, a

9 De Geouffre de la Pradelle protiv Francuske, presuda, 12964/87, 16. prosinca 1992.

10 Ashingdane protiv Ujedinjenog Kraljevstva, presuda, 8225/78, 28. svibnja 1985.

11 Prema Golder protiv Ujedinjenog Kraljevstva, presuda (4451/70, 21. veljače 1975.)

“38. (...) Sud smatra da pravo pristupa sudovima nije apsolutno. Budući da na to pravo Konvencija upućuje (...), a da ga pritom, u užem smislu riječi, ne određuje ovdje, osim granica koje određuju sam sadržaj svakog prava, ima prostora i za ograničenja koja su dopuštena implicitno (by implication)." 
postoji razumna veza razmjernosti između primijenjenih sredstava i legitimnog cilja koji se želi ostvariti (...).

56. Sud dalje podsjeća da kad ocjenjuje usklađenost s gore navedenim standardima, njegova zadaća nije zamijeniti nadležne domaće vlasti pri utvrđivanju najprikladnijih načina reguliranja pristupa pravdi niti ocjenjivati činjenice koje su navele te sudove da usvoje jednu odluku, a ne neku drugu. Uloga Suda jest preispitati, prema odredbama Konvencije, odluke koje su te vlasti donijele u izvršavanju svojih ovlasti ocjenjivanja i uvjeriti se jesu li posljedice tih odluka u skladu s Konvencijom (...).

57. I dalje s tim u vezi, Sud konačno želi ponoviti da je njegovo ispitivanje temeljeno na načelu da je namjera Konvencije zajamčiti ne prava koja su teorijska ili prividna (illusory), već prava koja su provediva u praksi (practical) i djelotvorna. To je naročito tako u pogledu prava na pristup sudovima u smislu važnog mjesta koje pravo na pošteno suđenje ima u demokratskom društvu (...)."

Uvjete pod kojima je dopušteno ograničiti pravo na pristup sudu Europski sud je istaknuo i u presudi Princ Hans - Adam II. od Lihtenštajna protiv Njemačke (2001.)

“59. (...) ograničenje pristupa njemačkom sudu, kao posljedica Konvencije o nagodbi, imalo je legitimni cilj.

69. (...) Sud smatra da interes podnositelja u pokretanju parnice u Saveznoj Republici Njemačkoj nije bio dostatan da prevagne nad vitalnim javnim interesom (...). Sukladno tome, odluke njemačkog suda kojima se vlasnička tužba podnositelja proglašava nedopuštenom ne mogu se smatrati nerazmjernima s obzirom na legitimni cilj kojem se težilo i one, prema tome, nisu ugrozile samu bit (the very essence) prava podnositelja na "pristup sudu" u onom značenju koje ono ima u praksi suda (...)."13

Uzimajući u obzir izložena stajališta Europskog suda glede dopuštenih ograničenja prava na pristup sudu, može se zaključiti da se propisivanjem obveznog upravnog postupka u hrvatskom pravu prije podnošenja tužbe sudu ostvaruje legitimni cilj (postignućem nagodbe pred upravnim tijelom o postojanju štete te vrsti i visini naknade skraćuje se postupak za naknadu štete i smanjuju broj sudskih tužbi), ne ugrožava se bit (the very essence) prava na pristup sudu (jer ako se nagodba ne dostigne, oštećenik može podnijeti tužbu sudu) te postoji razuman odnos razmjernosti (reasonable relationship of proportionality) između primijenjenog sredstva i cilja koji se želi postići. Prema svemu, u ovom slučaju ne postoji povreda prava na pristup sudu zajamčenog člankom 6. stavkom 1. Konvencije.

\section{PRAVNA OSNOVA NAKNADE ŠTETE ZBOG NEOPRAVDANE OSUDE ILI NEUTEMELJENOG UHIĆENJA}

Prema gledištu pravne teorije s kraja XIX. stoljeća, naknada štete zbog neopravdanog ograničenja slobode odgovarala je pravnom osjećaju, ali je glavni ako ne i jedini razlog zbog kojeg 
nije šire prihvaćena bio taj što se dogmatično-juristički nije mogla obrazložiti. ${ }^{14}$ Jedni su autori zastupali shvaćanje prema kojem je naknada "pravna dužnost države", drugi da je ona "dužnost po pravici", a traći da je kombinacija "pravne dužnosti države" i "dužnosti po pravici."15

Važno je napomenuti da naknada štete ne pretpostavlja krivnju državnog odvjetnika, suca ili neke treće osobe (svjedoka, vještaka i dr.). Ona uključuje i slučajeve u kojima bilo čije krivnje nema (primjerice naknadno su se pojavile nove činjenice i novi dokazi). Stoga pravnu osnovu odgovornosti za štetu zbog neopravdane osude ili neutemeljenog uhićenja ne možemo naći u općim pravilima građanskog prava. ${ }^{16}$ Odgovornost za štetu prema tim pravilima uvjetovana je krivnjom onoga koji je nanio štetu i samo se od te osobe može tražiti naknada. Ako je šteta nastala bez ičije krivnje, naknada se ne može ostvariti. Uostalom, kada bi se pravo osuđenika ili uhićenika na naknadu štete moglo ostvariti primjenom općih pravila građanskog prava, onda posebni propisi o tome ostvarivanju (oko kojih se spori pripadaju li građanskom ili kaznenom pravu $^{17}$ ) ne bi ni trebali postojati.

Suglasno shvaćanju teorije građanskog prava prema kojem se pravna osnova naknade štete svodi na pravnu normu kojom se nekom nalaže dužnost popravljanja štete, ${ }^{18}$ pravnu osnovu naknade o kojoj ovdje govorimo čine pravila međunarodnog i ustavnog prava koja naknadu štete utvrđuju kao subjektivno javno pravo neopravdano osuđene ili neutemeljeno uhićene osobe, kojem odgovara pravna dužnost države da naknadi štetu. Riječ je o subjektivnom pravu jer se ono odnosi na privatni interes oštećenika, ali i o javnom pravu jer je u javnom interesu da nedužni građanin ne bude neopravdano osuđen ili neutemeljeno uhićen. ${ }^{19}$

\section{PRAVNO UREĐENJE NAKNADE ŠTETE ZBOG NEOPRAVDANE OSUDE ILI NEUTEMELJENOG UHIĆENJA ILI PRITVARANJA}

\section{MEĐUNARODNI DOKUMENTI I PRAKSA EUROPSKOG SUDA}

U ovom su vremenu brojni međunarodni dokumenti, paktovi i konvencije posvećeni standardima ljudskih prava i sloboda te međunarodnim mehanizmima i institucijama za njihovu zaštitu. Odnosi se to i na standarde koji se tiču ostvarivanja prava na naknadu štete za neopravdanu osudu ili neutemeljeno uhićenje.

14 Vesel, koji iznosi shvaćanje njemačkog autora Adolfa Merkela, op. cit., str. 8.

15 Vesel, op. cit., str. 7., str. 8.

16 O tim pravilima v. Petar Klarić, Odštetno pravo, četvrto izmijenjeno i prošireno izdanje, Narodne novine, Zagreb, veljača 2003. Ivica Crnić, Odštetno pravo, drugo bitno izmijenjeno i dopunjeno izdanje, Zgombić i partneri.

17 Vidjeti o tome pobliže Momčilo Grubač, Naknada štete za neopravdanu osudu ili neosnovano lišenje slobode, Savremena administracija, Beograd, 1979., str. 14.

18 Klarić, op. cit., str. 166. To je stajalište veoma staro. Vesel, pozivajući se na strane autore s početka prošlog stoljeća, navodi: “(...) strogo uzevši pravni razlozi postoje samo u postojećem pravu (...), pa ako pravica diktira zakon, postaje pravica tek zakonom pravo... se o pravnoj dužnosti uopće ne može govoriti dok je pozitivno pravo ne ustanovljuje" (Vesel, op. cit., str. 10., bilj. 10.). 
Međunarodni pakt o građanskim i političkim pravima (dalje: Međunarodni pakt) ${ }^{20}$ propisuje: "Svaka osoba koja je žrtva nezakonitog uhićenja ili pritvora ima pravo na naknadu štete" (čl. 9. st. 5.). "Ako konačno izrečena presuda bude kasnije poništena ili ako je dano pomilovanje zbog toga što nova činjenica ili naknadno otkrivena dokazuje da se radilo o sudskoj grešci, osoba koja je izdržala kaznu na osnovi ove osude bit će obeštećena prema zakonu, ukoliko se ne dokaže da je ona u potpunosti ili djelomično kriva za nepravodobno otkrivanje nepoznate činjenice" (čl. 14. st. 6.). Vidimo da je Međunarodni pakt propisao pravo na naknadu štete zbog nezakonitog uhićenja ili pritvora i zbog neopravdane presude.

Konvencija, u članku 5. stavka 5., priznaje pravo na odštetu svakome tko je žrtva uhićenja ili pritvaranja suprotno odredbama stavka 1. toga članka (u odredbama se st. 1. t. a) do f) nabrajaju slučajevi u kojima je dopušteno lišenje slobode i u postupku propisanom zakonom). Prema Europskom sudu, svrha je toga članka "zaštita tjelesne slobode pojedinaca i njihova osobna sigurnost” protiv “arbitrarnog lišenja slobode” (presuda Kurt protiv Turske, 1998.). Pravo na naknadu štete zbog neopravdane presude nije predviđeno. Izvorno se smatralo, prema nekim autorima pod utjecajem common lawa i općeg pravila the King can do no wrong, ${ }^{21}$ da je propisivanje potonje navedenog prava, kraj prvonavedenog, suvišno. No pravo na naknadu štete zbog "pogrešne osude" (wrongful conviction) uvedeno je člankom 3. Protokola br. 7. uz Konvenciju od 22. studenog 1984. koji pod naslovom "Naknada za pogrešnu odluku" (Compensation for wrongful conviction) glasi: "Kad je neka osoba osuđena pravomoćnom presudom za kazneno djelo i kad je naknadno njezina presuda poništena, ili je ta osoba pomilovana na temelju novih ili novootkrivenih činjenica koje upućuju na pogrešnu presudu, osoba koja je izdržala kaznu kao posljedicu te presude obeštetit će se u skladu sa zakonom ili praksom dotične države, osim ako se dokaže da je sama djelomice ili u cijelosti odgovorna za zakašnjelo utvrđenje do tada nepoznatih činjenica." 22 Pod uvjetima iz citiranog članka država stranka konvencije dužna je naknaditi štetu zbog pogrešne osude "u skladu sa zakonom ili praksom dotične države”. Prema objašnjenju Protokola br. 7. uz Konvenciju svrha je njegova donošenja dogradnja zaštite ljudskih prava sukladno preporukama Parlamentarne skupštine i Ministarskog odbora Vijeća Europe. ${ }^{23}$

Prema iznesenom, Međunarodni pakt u članku 9. stavku 5. predviđa pravo na naknadu štete žrtvi nezakonitog uhićenja ili pritvora, dok Konvencija u članku 5. stavku 5. propisuje pravo na odštetu žrtvi zbog uhićenja ili pritvaranja suprotno odredbama stavka 1. toga članka (što znači suprotno zakonitom uhićenju ili pritvaranju). Proizlazi da Međunarodni pakt i Konvencija utvrđuju pravo na odštetu žrtvama nezakonitog, ali ne i neutemeljenog uhićenja ili pritvora.

20 Međunarodni pakt o građanskim i političkim pravima (Narodne novine - Međunarodni ugovori, broj 12/1993, 7/1995).

21 Vidjeti Weissbrodt, D., The Right to a Fair Trial: Articles 8, 10 and 11 of the UDHR, M. Nijhoff Publishers, The Hague, 2001., str. 53.

22 "When a person has by a final decision been convicted of a criminal offence and when subsequently his conviction has been reversed, or he has been pardoned, on the ground that a new or newly discovered fact shows conclusively that there has been a miscarriage of justice, the person who has suffered punishment as a result of such conviction shall be compensated according to the law or the practice of the State concerned, unless it is proved that the non-disclosure of the unknown fact in time is wholly or partly attributable to him." 
No, Europski sud je u svojoj praksi, teleološkom interpretacijom ${ }^{24}$ odredbe članka 5. stavka 5. Konvencije pravo na odštetu proširio i na slučajeve neutemeljenog uhićenja ili pritvaranja. Razmatrajući značenje pojma "zakonitost" (lawfulness) lišenja slobode iz članka 5. stavka 4. Konvencije Europski sud je u predmetu Brogan i drugi protiv Ujedinjenog Kraljevstva (1988. $)^{25}$ naveo:

“65. (...) pojam 'zakonitost' u stavku 4. (...) ima isto značenje kao i u stavku 1. (...); mogu li se 'uhićenje' ili 'pritvaranje' smatrati zakonitim, mora biti utvrđeno ne samo u svjetlu domaćeg prava već i teksta Konvencije, općih načela utjelovljenih u njima i cilja ograničenja dopuštenih člankom 5. stavkom 1. (...) uhićene ili pritvorene osobe imaju pravo na nadzor procesnih i materijalnih uvjeta koji su bitni za 'zakonitost', u smislu Konvencije, njihova lišenja slobode (...)."

U presudi Stanev protiv Bugarske (2012.) ${ }^{26}$ Europski sud je zaključio:

“182. (...) djelotvorno uživanje prava na naknadu štete zajamčeno člankom 5. stavkom 5. mora biti osigurano dostatnim stupnjem izvjesnosti (with a sufficient degree of certainty) (...)."

Izloženom interpretacijom "zakonitosti” lišenja osobne slobode Europski sud je pravo na naknadu štete za nezakonito uhićenje ili pritvor zapravo sveo na naknadu (u smislu Konvencije) za neutemeljeno uhićenje ili pritvor. ${ }^{27}$

\section{PRAVO REPUBLIKE HRVATSKE}

\subsection{Ustavno pravo}

Kako je to uvodno već rečeno, URH u članku 25. stavku 4. sadrži odredbu koja glasi: "Svatko tko je bio nezakonito lišen slobode ili osuđen ima, u skladu sa zakonom, pravo na odštetu i javnu ispriku." Ustavna odredba, dakle, govori o "nezakonitom" lišenju slobode ili osudi. Vidjeli smo, međutim, da je odredbom članka 3. Protokola br. 7. uz Konvenciju predviđena naknada štete zbog "pogrešne" osude koja se razumijeva kao "neopravdana" osuda, a zatim i da je Europski sud tumačenjem značenje pojma "zakonitost” lišenja slobode iz članka 5. stavka 4. Konvencije naknadu štete zbog nezakonitog uhićenja ili pritvora u svojoj praksi proširio na slučajeve neutemeljenog uhićenja ili pritvora.

U odnosu na izneseno važna je odluka Ustavnog suda RH U-III-1839/06 od 7. svibnja 2009. kojom je usvojena ustavna tužba podnositelja protiv odluka redovnih sudova kojima je odbijen njegov tužbeni zahtjev za naknadu štete. U toj odluci Ustavni sud RH navodi da razlozi za

24 O toj interpretaciji kao "sidrištu" načela interpretacije konvencijskog prava v. Greer, S., The European Convention on Human Rights, Achievements, Problems and Prospects, Cambridge Studies in European Law and Policy, Cambridge: Cambridge University Press, 2006., str. 195.

25 Brogan i drugi protiv Ujedinjenog Kraljevstva, presuda, 11209/84, 11234/84, 11266/84, 11386/85, 29. studenog 1988.

26 Stanev protiv Bugarske, presuda, 36760/06, 17. siječnja 2012.

27 Već Vesel ispravno iznosi: “(...) lučimo protuzakonito određeni pritvor odn. istražni zatvor od nepravedno određenog pritvora odnosno istražnog zatvora” (Vesel, op. cit., str. 6.). 
određivanje pritvora, njegova zakonitost ili nezakonitost, kao i razlozi za obustavu postupka, nemaju utjecaja na utvrđivanje osnovanosti zahtjeva za naknadu štete primjenom članka 480. stavka 1. točka 1., nego je bitno da protiv osobe koja je bila u pritvoru nije došlo do pokretanja kaznenog postupka ili je postupak obustavljen pravomoćnim rješenjem ili je pravomoćnom presudom oslobođena optužbe ili je optužba odbijena. Kada se uzme u obzir navedena odluka, može se konstatirati da Ustavni sud RH u svojoj praksi primjenjuje navedeno (prošireno) konvencijsko pravo glede naknade štete i na taj način jača i širi zaštitu ljudskih prava. ${ }^{28}$

\subsection{Zakonsko pravo}

Posebne zakonske odredbe kojima je normiran postupak za naknadu štete i ostvarivanje drugih prava neopravdano osuđenih ili neutemeljeno uhićenih osoba sadržane su u člancima 476. do 484.a. ${ }^{29}$

\subsubsection{Naknada štete zbog neopravdane osude}

Prema članku 476. stavku 1. "Pravo na naknadu štete zbog neopravdane osude ima osoba prema kojoj je bila pravomoćna izrečena kaznena sankcija ili koja je proglašena krivom, a oslobođena kazne, a kasnije je u povodu izvanrednog pravnog lijeka novi postupak pravomoćno obustavljen, ili je pravomoćnom presudom oslobođena optužbe ili je optužba odbijena, osim ako je do obustave postupka ili presude kojom se optužba odbija došlo zato što je u novom postupku oštećenik kao tužitelj, odnosno privatni tužitelj odustao od progona ili što je oštećenik odustao od prijedloga, a do odustanka je došlo na temelju sporazuma s okrivljenikom." Ali, prema članku 476. stavku 2. "Osuđenik nema pravo na naknadu štete ako je svojim lažnim priznanjem ili na drugi način namjerno prouzročio svoju osudu, osim ako je na to bio prisiljen."

Citiranim su zakonskim propisima određeni uvjeti za naknadu štete zbog neopravdane osude, i to kako pozitivni, tako i negativni uvjeti. ${ }^{30}$

a) Postojanje pravomoćne osude te da je ona poslije u postupku u povodu izvanrednog pravnog lijeka promijenjena pozitivni su uvjeti.

Prvi je, dakle, pozitivni uvjet da postoji pravomoćna osuda kojom je izrečena kaznena sankcija. Hrvatsko kazneno pravo ${ }^{31}$ poznaje tri vrste kaznenopravnih sankcija: kazne (novčana kazna, zatvor i dugotrajni zatvor), sigurnosne mjere i odgojne mjere. Prema važećem Kaznenom zakonu Republike Hrvatske, Narodne novine, broj 125/2011, 144/2012, 56/2015, 61/2015, 101/2017 (dalje: KZH) uvjetna osuda i rad za opće dobro nisu samostalne kaznenopravne sankcije, nego se smatraju modifikacijom ili supstitutom kazne. Stoga su sadržane u glavi IV. KZH-a koja propisuje kazne. Posebne kaznenopravne mjere iz glave VI. (oduzimanje imovinske koristi, oduzimanje predmeta i javno objavljivanje presude) KZH ne smatra kazne-

28 Više o toj odluci: Davor Krapac, Bagić Snježana, Pravo na naknadu štete zbog neopravdane osude ili zbog neutemeljenog uhićenja ili pritvaranja te njegova suvremena ustavnopravna i kaznenopravna regulacija, Zbornik Pravnog fakulteta u Zagrebu, 62 (5-6) (2012), str. 1264., 1265.

29 Vidjeti bilj. 5.

30 Usp. Krapac, Bagić, op. cit., str. 1266.-1274.

31 Kazneni zakon i Zakon o sudovima za mladež. 
nopravnim sankcijama. ${ }^{32}$ Naknada pripada i osobi koja je proglašena krivom, a oslobođena je kazne. Osuda može biti izrečena presudom ili rješenjem (u slučaju pojedinih sigurnosnih mjera ili odgojnih mjera). Pravo na naknadu nastaje samim izricanjem osude na bilo koju vrstu ili mjeru kaznene sankcije, neovisno o tome je li ona izvršena ili nije, ali ne i zbog neopravdano vođenog postupka u kojem je donesena sudska odluka. ${ }^{33}$ Prema članku 476. stavku 3. "U slučaju osude za kaznena djela u stjecaju pravo na naknadu štete može se odnositi i na pojedina kaznena djela glede kojih je udovoljeno uvjetima za priznanje naknade." Sukladno toj odredbi, naknadnom obnovom postupka, oslobođenjem od optužbe ili odbijanjem optužbe za pojedina kaznena djela stječe se pravo na naknadu štete za dio osude koji se tiče tih kaznenih djela. ${ }^{34}$

Drugi je pozitivni uvjet da je pravomoćna osuda poslije u povodu izvanrednog pravnog lijeka promijenjena na način da je novi postupak pravomoćno obustavljen ili je pravomoćno osuđena osoba oslobođena optužbe ili je optužba odbijena. Pritom je irelevantno je li izvanredni pravni lijek podnesen u korist ili na štetu osuđene osobe, kao i je li neopravdana osuda posljedica pogreške glede činjeničnih ili pravnih pitanja.

b) Postojanje negativnih uvjeta isključuje pravo na naknadu štete zbog neopravdane osude iako su pozitivni uvjeti za tu naknadu ispunjeni. Zakonom su predviđena dva negativna uvjeta.

Prvi je negativni uvjet “(...) ako je do obustave postupka ili presude kojom se optužba odbija došlo zato što je u novom postupku oštećenik kao tužitelj, odnosno privatni tužitelj odustao od progona ili što je oštećenik odustao od progona, a do odustanka je došlo na temelju sporazuma s okrivljenikom" (čl. 476. st. 1.). Ovdje je riječ o sporazumu (nagodbi) okrivljenika s oštećenikom, oštećenikom kao tužiteljem ili privatnim tužiteljem koji ima za posljedicu obustavu novog postupka ili u tome postupku presudu kojom se optužba odbija. Taj sporazum ima nadmoćno građanskopravnu prirodu i stoga država nakon što je on postignut nije dužna nadoknaditi štetu zbog neopravdane osude.

Drugi je negativni uvjet “(...) ako je osuđenik svojim lažnim priznanjem ili na drugi način namjerno prouzročio svoju osudu, osim ako je na to bio prisiljen” (čl. 476. st. 2.). Prema shvaćanju procesne teorije osuđenik je lažnim priznanjem prouzročio svoju osudu kada se ona temelji na tome priznanju, a ne na drugim izvedenim dokazima, što mora biti vidljivo u obrazloženju osude. Teškoće nastaju ako osuda kada je to zakonom dopušteno ne sadrži obrazloženje. U tim slučajevima parnični sud može koristiti zapisnike iz kaznenog spisa o izvedenim dokazima. ${ }^{35}$

Osuđenik može osudu prouzročiti, izuzimajući lažno priznanje, i "na drugi način”, tako primjerice podnošenjem lažnih dokaza o počinjenju kaznenog djela i krivnji. Nije uskraćeno pravo na naknadu štete u slučaju u kojem osuđenik namjerno ne izjavi žalbu protiv prvostupanjske presude i na taj način prouzroči neopravdanu osudu jer to, za razliku od prijašnjih

32 Petar Novoselec, Opći dio kaznenog prava, Peto izmijenjeno izdanje, Pravos, Osijek, 2016., str. 357.

33 Tako i Vrhovni sud Republike Hrvatske. Primjerice, u jednom predmetu Vrhovni sud utvrđuje da su sudovi osnovano zaključili kako u konkretnom slučaju tužitelj nije bio neopravdano osuđena osoba, budući da u tijeku kaznenog postupka nije bio oglašen krivim, a sama okolnost vođenja kaznenog postupka protiv tužitelja nije od značaja za postojanje odštetne odgovornosti tuženika (Rev 2320/1997 od 26. siječnja 2000.). U tim je slučajevima moguće tražiti naknadu štete zbog nepravilnog ili nezakonitog rada suca ili državnog odvjetnika, odnosno njegova zamjenika (v. gore pod I.). 
zakonskih propisa, ${ }^{36}$ u članku 476. stavku 2., nije predviđeno. Ni šutnja okrivljenika ne isključuje pravo na naknadu štete zato što se on u postupku može braniti šutnjom i neiznošenjem dokaza u svoju korist. ${ }^{37}$

Osuđenik mora namjerno prouzročiti svoju osudu i to se utvrđuje u odštetnoj parnici. Riječ je o izravnoj namjeri što znači da postoji svijest i volja (htijenje) za ostvarenje neopravdane osude. U tome slučaju nema odgovornosti države za štetu sukladno poznatoj latinskoj izreci volenti non fit iniuria (onomu koji pristaje, ne čini se nepravda).

\subsubsection{Naknada štete zbog neutemeljenog uhićenja ili pritvaranja}

Odredbama članka 480. stavka 1.-3. propisano je: "Pravo na naknadu štete pripada i osobi: 1) koja je bila u pritvoru, a nije došlo do pokretanja kaznenog postupka, ili je postupak obustavljen pravomoćnim rješenjem, ili je pravomoćnom presudom oslobođena optužbe, ili je optužba odbijena, 2) koja je izdržala kaznu oduzimanja slobode, a u povodu izvanrednog pravnog lijeka izrečena joj je kazna oduzimanja slobode u kraćem trajanju od kazne koju je izdržala, ili je izrečena kaznena sankcija koja se ne sastoji u oduzimanju slobode, ili je proglašena krivom, a oslobođena od kazne, 3) koja je zbog pogreške ili protuzakonitog rada državnog tijela neosnovano uhićena ili pritvorena, ili je zadržana preko zakonskog roka, ili je preko tog roka bila u pritvoru ili u ustanovi za izdržavanje kazne, 4) koja je u pritvoru provela dulje vrijeme nego što traje kazna zatvora na koju je osuđena (st. 1.); Osobi koja je prema članku 95. ovog Zakona uhićena bez zakonske osnove pripada pravo na naknadu štete ako protiv nje nije određen pritvor niti joj vrijeme za koje je bila uhićena nije uračunato u izrečenu kaznu za kazneno djelo ili za prekršaj (st. 2.); Naknada štete ne pripada osobi koja je svojim nedopuštenim postupcima prouzročila uhićenje. U slučajevima iz točke 1. stavka 1. ovog članka isključeno je pravo na naknadu štete i ako su postojale okolnosti iz članka 95. ovog Zakona (st. 3.).”

Detaljnijim razmatranjem citiranih odredbi može se zaključiti: prvo, da one utvrđuju pozitivan i negativan uvjet za naknadu štete zbog neutemeljenog uhićenja ili pritvaranja te drugo, da je "neutemeljeno" uhićenje ili pritvaranje širi pojam koji uključuje kako "neopravdano" ("pogrešno" prema članku 3. Protokola br. 7. uz Konvenciju), tako i "nezakonito" uhićenje ili pritvaranje. $^{38}$

a) Neutemeljeno uhićenje ili pritvaranje kao pozitivan uvjet

Prema članku 480. neutemeljeno uhićenje obuhvaća:

(1) nezakonito uhićenje (st. 1.t. 3.) - osoba je zbog pogreške ili protuzakonitog rada državnog tijela uhićena ili je zadržana preko zakonskog roka te

36 Prema članku 466. stavku 3. Zakona o sudskom krivičnom postupku Kraljevine Jugoslavije iz 1929. i članku 472. Zakona o krivičnom postupku iz 1953. bivše Jugoslavije to je bila negativna pretpostavka za naknadu štete.

37 Grubač, op. cit., str. 41.

38 Usp. Krapac, Bagić, op. cit., str. 1274.-1277. 
(2) neopravdano uhićenje (st. 2.) - osoba je uhićena bez zakonske osnove (prema čl. 95.), ${ }^{39}$ a protiv nje nije određen pritvor niti joj je vrijeme za koje je bila uhićena uračunato u izrečenu kaznu.

Prema navedenom članku neutemeljeno pritvaranje je:

(1) nezakonito pritvaranje (st. 1. t. 3.) - osoba je zbog pogreške ili protuzakonitog rada državnog tijela pritvorena ili je bila u pritvoru preko zakonskog roka te

(2) neopravdano pritvaranje (st. 1. t. 1.) - osoba je bila u pritvoru (zakonitom - B. Lj.), ali nije došlo do pokretanja kaznenog postupka ili je postupak obustavljen pravomoćnim rješenjem ili je pravomoćnom presudom oslobođena optužbe ili je presudom optužba odbijena, odnosno (st. 1. t. 4.) - osoba je u pritvoru provela dulje vrijeme nego što traje kazna zatvora na koju je osuđena.

b) Uhićenik je svojim nedopuštenim postupcima prouzročio uhićenje i pritvor kao negativan uvjet

Prema članku 480. stavku 3. naknada štete za neutemeljeno uhićenje ili pritvor ne pripada osobi koja je svojim nedopuštenim postupcima prouzročila uhićenje. Prema stajalištu sudske prakse, utvrđuje u jednoj svojoj odluci Vrhovni sud RH, nedopušteni postupci samo su takvi postupci kojima osoba protiv koje je kazneni postupak pokrenut na bilo koji način želi i stvarno izražava svoj negativni stav u smislu dovršenja postupka, izbjegavanja odgovornosti, onemogućavanja postupanja u odnosu prema inkriminiranom djelu - konkretno, kad npr. nevina osoba pokušava pobjeći iz zemlje zbog straha od pritvaranja, kad uništava dokumente, skriva dokaze i sl. - a ne sama okolnost da je takva osoba jedino propustila, zbog razloga za koje nije utvrđeno da su uopće u vezi s kaznenim postupkom, odjaviti odnosno prijaviti svoje boravište (Rev 1408/81 - 2 od 22. prosinca 1981.). U odštetnoj se parnici mora utvrditi nedopušteno postupanje uhićenika te njegova svijest i volja (htijenje) da se ostvari uhićenje ili pritvaranje.

\subsubsection{Vrste i oblici naknade štete}

Neopravdano osuđena ili neutemeljeno uhićena ili pritvorena osoba ima pravo na sve oblike naknade imovinske i neimovinske štete propisane Zakonom o obveznim odnosima (Narodne novine, broj 35/2005, 41/2008, 125/2011, 78/2015) te u obujmu određenom tim Zakonom. Neimovinska šteta može se popraviti u novčanom i nenovčanom obliku (priopćenjem u novinama ili drugom javnom sredstvu priopćavanja, članak 481.). ${ }^{40},{ }^{41}$

I prema stajalištu Europskog suda, šteta može biti imovinska i neimovinska, s tim da je novčana naknada pravilo. Određujući pravednu naknadu na osnovi članka 41. Konvencije Europski sud je u presudi Rakevich protiv Rusije (2003.) ${ }^{42}$ izrazio sljedeće stajalište:

\footnotetext{
39 Članak 95. propisuje slučajeve u kojima su redarstvene vlasti ovlaštene uhititi osobu.

40 Crnić, op. cit., str. 271., str. 621.

41 Za priznanje radnog staža, odnosno staža osiguranja v. članak 484.

42 Rakevich protiv Rusije, presuda, 58973/00, 28. listopada 2003.
} 
“53. Sud primjećuje da neki oblici neimovinske štete, uključujući emocionalnu bol, po samoj svojoj naravi ne mogu uvijek biti predmet konkretnog dokaza (...) to ne sprječava Sud da odredi odštetu ako smatra da je razumno pretpostaviti da je podnositelj pretrpio štetu koja zahtijeva novčanu kompenzaciju. U konkretnom slučaju razumno je pretpostaviti da je podnositeljica pretrpjela bol, tjeskobu i frustraciju zato što njezino pritvaranje, mnogo dana, nije bilo zasnovano na sudskoj odluci."

U vezi s iznosom naknade koja treba biti dodijeljena na temelju članka 5. stavka 5. Konvencije, Europski sud ne utvrđuje smjernice, ali u predmetu X. protiv Ujedinjenog Kraljevstva $(1981 .)^{43}$ zaključuje da dodijeljeni iznos mora odražavati težinu povrede pravnih propisa.

\subsubsection{Postupak za naknadu štete}

Kao što je već navedeno (pod II.), oštećenik je prije podnošenja tužbe za naknadu štete dužan obratiti se svojim zahtjevom Ministarstvu pravosuđa zbog postignuća nagodbe o postojanju štete te vrsti i visini naknade (čl. 477. st. 2.). U slučaju da taj zahtjev ne bude prihvaćen ili o njemu ne bude odlučeno u roku od tri mjeseca od podnošenja zahtjeva, oštećenik može kod nadležnog suda podnijeti tužbu za naknadu štete. Ako je nagodba postignuta samo u dijelu zahtjeva, oštećenik može podnijeti tužbu glede ostatka zahtjeva. Tužba se podnosi protiv Republike Hrvatske (čl. 478. st. 1. i 3.).

Pravo na naknadu štete zastarijeva za tri godine od dana pravomoćnosti prvostupanjske presude kojom je okrivljenik oslobođen optužbe ili kojom je optužba odbijena, odnosno pravomoćnosti prvostupanjskog rješenja kojom je postupak obustavljen, a ako je u povodu žalbe rješavao viši sud, od dana primitka odluke višeg suda (čl. 477. st. 1.). Nasljednici nasljeđuju samo pravo oštećenika na naknadu imovinske štete. Ali ako je oštećenik već podnio zahtjev za naknadu štete, nasljednici mogu nastaviti postupak samo u granicama već postavljenog zahtjeva. Nasljednici mogu nastaviti, odnosno pokrenuti postupak za naknadu štete pod uvjetom da je oštećenik umro prije proteka roka zastare i nije se odrekao zahtjeva (čl. 479.).

\section{PODACI O PRAKSI UPRAVNOG STADIJA OSTVARIVANJA PRAVA NA NAKNADU ŠTETE}

Za potrebe ovog rada na naš zahtjev dobili smo od Ministarstva pravosuđa ${ }^{44}$ podatke $\mathrm{e}^{45} \mathrm{o}$ praksi upravne faze postupanja u povodu zahtjeva oštećenika za naknadu štete za neopravdanu osudu ili neutemeljeno uhićenje ili pritvaranje. Prikazujemo ih u tablici koja slijedi:

43 X. protiv Ujedinjenog Kraljevstva, presuda, 7215/75, 5. studenog 1981.

44 Uz pomoć i razumijevanje gospodina Božidara Horvata, predsjednika Upravnog suda u Osijeku.

45 Uz dostavljene podatke resorno Ministarstvo navodi kako "od 2010. - 2012. godine nije se vodila statistika, a i predmeti se nalaze u arhivi (...)", te "da podaci isplaćenih novčanih naknada u jednoj godini su isplate po predmetima iz više godina." 


\begin{tabular}{|l|l|l|l|l|}
\hline Godina & $\begin{array}{l}\text { Zaprimljeno zahtjeva } \\
\text { za naknadu štete }\end{array}$ & $\begin{array}{l}\text { Riješeno } \\
\text { zahtjeva }\end{array}$ & $\begin{array}{l}\text { Isplaćeno u kn za } \\
\text { neopravdanu osudu }\end{array}$ & $\begin{array}{l}\text { Isplaćeno u kn za } \\
\text { neutemeljeno uhićenje } \\
\text { ili pritvaranje }\end{array}$ \\
\hline 2010. & 205 & $\begin{array}{l}\text { Nije vođena } \\
\text { statistika }\end{array}$ & & $3.669 .993,64$ \\
\hline 2011. & 226 & $\begin{array}{l}\text { Nije vođena } \\
\text { statistika }\end{array}$ & & $3.022 .521,00$ \\
\hline 2012. & 226 & $\begin{array}{l}\text { Nije vođena } \\
\text { statistika }\end{array}$ & & $2.415 .081,16$ \\
\hline 2013. & 178 & 74 & & $934.043,00$ \\
\hline 2014. & 187 & 85 & & $1.262 .620,00$ \\
\hline 2015. & 181 & 67 & & $825.020,00$ \\
\hline 2016. & 167 & 51 & & $391.240,00$ \\
\hline Ukupno & 1370 & 277 & $12.520 .518,80$ \\
\hline
\end{tabular}

Iz tablice je vidljivo da je u razdoblju od 2010. do 2016. godine broj zaprimljenih zahtjeva Ministarstvu pravosuđa za naknadu štete zbog neutemeljenog uhićenja ili pritvaranja znatan (1370 zahtjeva). Podatak o broju riješenih zahtjeva postignućem nagodbe (277) nepotpun je jer za razdoblje od 2010. do 2012. godine "nije vođena statistika" takvih zahtjeva. Naknada je isključivo novčana i samo zbog neutemeljenog uhićenja ili pritvaranja. Ukupan iznos naknade u prve tri godine razmatranog razdoblja (od 2010. do 2012.) izrazito je velik $(9.107 .595,80$ $\mathrm{kn}$ ), dok je u sljedeće četiri godine (od 2013. do 2016.) znatno manji (3.412.923,00 kn). I prema podacima koje su za prethodno razdoblje od 2004. do 2008. godine pribavili Krapac i Bagić, broj zaprimljenih zahtjeva oštećenika Ministarstvu pravosuđa za naknadu štete je znatan (1038 zahtjeva), broj riješenih zahtjeva je gotovo upola manji (538), a ukupno isplaćena suma na temelju nagodbi također velika $(12.057 .038,82 \mathrm{kn}){ }^{46}$ Tendencija ovako visokih razina zaprimljenih zahtjeva i isplaćenih iznosa zaustavljena je u razdoblju od 2013. do 2016. godine, nešto manje u odnosu na broj zaprimljenih zahtjeva, a znatno u odnosu na isplaćene svote novca na temelju nagodbi (ukupno 3.412.923,00 kn).

\section{ZAKLJUČCI}

Propisivanjem obvezne upravne faze postupka prije podnošenja tužbe sudu protiv Republike Hrvatske za naknadu štete za neopravdanu osudu ili neutemeljeno uhićenje ili pritvaranje, hrvatsko pravo ne krši implicirano konvencijsko "pravo na pristup sudu". Sukladno stajalištima Europskog suda, ovdje je riječ o dopuštenim ograničenjima "prava na pristup sudu" zajamčenog člankom 6. stavkom 1. Konvencije. To zato što se ostvaruje legitimni cilj (dostignućem nagodbe pred upravnim tijelom skraćuje se postupak za naknadu štete i smanjuje broj sudskih tužbi), ne ugrožava se bit (the very essence) prava na pristup sudu (jer ako se nagodba ne dostigne, oštećenik može podnijeti tužbu sudu) te postoji razborit omjer razmjernosti (re- 
asonable relationship of proportionality) između propisanog sredstva ograničavanja i cilja koji se želi postići.

Pravnu osnovu naknade štete čine pravila međunarodnog i ustavnog prava prema kojima je naknada štete subjektivno javno pravo neopravdano osuđene ili neutemeljeno uhićene ili pritvorene osobe, kojom odgovara dužnost države da štetu naknadi. Naknada je subjektivno pravo jer se tiče privatnoga interesa oštećenika, ali i javno pravo jer je u javnom interesu da nedužni građanin ne bude neopravdano osuđen ili neutemeljeno uhićen ili pritvoren.

Za razliku od URH koji u članku 25. stavku 4. propisuje pravo na naknadu štete osobi koja je bila "nezakonito" lišena slobode ili osuđena, članak 3. Protokola br. 7. uz Konvenciju iz 1984. godine uvodi pravo na naknadu štete zbog "pogrešne osude" (wrongful conviction) koja se shvaća kao "neopravdana osuda". Europski sud u svojoj praksi tumačenjem pojma "zakonitost” lišenja slobode iz članka 5. stavka 4. Konvencije naknadu štete za nezakonito uhićenje ili pritvor zapravo sveo na naknadu (u smislu Konvencije) za neutemeljeno uhićenje ili pritvor.

"Neutemeljeno" uhićenje ili pritvaranje je sukladno odredbama članka 480. širi pojam koji obuhvaća "neopravdano" (pogrešno prema članku 3. Protokola br. 7. uz Konvenciju) i "nezakonito" uhićenje ili pritvaranje.

Broj zahtjeva oštećenika za naknadu štete hrvatskom upravnom tijelu (Ministarstvu pravosuđa) je znatan, a broj riješenih zahtjeva je znatno manji. Naknada je isključivo novčana i samo zbog neutemeljenog uhićenja ili pritvaranja. Iznosi naknade, kao posljedica neprihvatljivo velikog broja neutemeljenih uhićenja i pritvaranja, veliki su. Tendencija visokih razina zaprimljenih zahtjeva i isplaćenih iznosa zaustavljena je u razdoblju od 2013. do 2016. godine, nešto manje u odnosu na broj zaprimljenih zahtjeva, a znatno u odnosu na isplaćene svote novca na temelju nagodbi.

\section{LITERATURA}

\section{KNJIGE I ČLANCI}

1. Bartlett, P., Lewis, O., Thorold, O., Mental Disability and the European Convention on Human Rights, Martinus Nijhoff, 2006.

2. Creifelds, Rechtswörtherbuch, 17. Auflage, Verlag C. H. Beck, München, 2002.

3. Crnić, I., Odštetno pravo, Drugo bitno izmijenjeno i dopunjeno izdanje, Zgombić i partneri.

4. Crnić, I., Odgovornost sudaca za štetu u zakonodavstvu i praksi Republike Hrvatske, Informator, br. 5336, 2005., str. 1.-4.

5. De Hert, P., Balancing Security and Liberty within the European Human RightsFramework. A critical Reading of the Court's Case Law in the Light of Surveillance and Criminal Law Enforcement Strategies after 9/11, Utrecht Law Review, Vol. 1, Issue 1, 2005.

6. Edel, F., The Length of Civil and Criminal Proceedings in the Case-law of the European Court of Human Rights, 2nd ed., Human rights files: No. 16, Council of Europe, Strasbourg, 2007.

7. Greer, V., The European Convention on Human Rights, Achievements, Problems and Prospects, Cambridge Studies in European Law and Policy, Cambridge: Cambridge University Press, 2006. 
8. Grubač, M., Naknada štete za neopravdanu osudu i neosnovano lišenje slobode, Savremena administracija, Beograd, 1979.

9. Ivančević, V., Odgovornost države za štetu nanesenu građanima protupravnim ponašanjem službenih osoba, Naša zakonitost, br. 1-2/1964., 24.-38.

10. Klarić, P., Odštetno pravo, četvrto izmijenjeno i prošireno izdanje, Narodne novine, Zagreb, veljača 2003.

11. Krapac, D., Bagić, S., Pravo na naknadu štete zbog neopravdane osude ili zbog neutemeljenog uhićenja ili pritvaranja te njegova suvremena ustavnopravna i kaznenopravna regulacija, Zbornik Pravnog fakulteta u Zagrebu, 62 (5-6) (2012), str. 1237.-1281.

12. Ljubanović, B., Sudačka neovisnost u Republici Hrvatskoj, u: Sud je u pravnom sistemu, Fondacija Centra za javno pravo, Sarajevo, 2013., str. 27.-144.

13. McBride, J., Pravo na slobodu i sigurnost ličnosti, Vodič za primjenu člana 5. Evropske konvencije o ljudskim pravima, br. 5., Publikacije Vijeća Europe, Strasbourg - Sarajevo, 2005.

14. Omejec, J., Konvencija za zaštitu ljudskih prava i temeljnih sloboda u praksi Europskog suda za ljudska prava, Strasbourški acquis, Novi informator, Zagreb, 2013.

15. Vesel, J., Naknada za nepravedno određen pritvor i istražni zatvor, Posebni otisak koreferata za II. Kongres pravnika Kraljevine S.H.S. održanog u Ljubljani od 9. - 11. septembra 1926 ., Ljubljana, 1927.

16. Weissbrodt, D., The right to a Fair Trial: Articles 8, 10 and 11 of the UDHR, M. Nijhoff Publishers, The Hague, 2001.

17. Šilović, J., Naknada štete za neopravdano određen pritvor i istražni zatvor, u: Spomenica na II. Kongres pravnika Kraljevine SHS, Ljubljana, 1927., 150.-157.

\section{MEĐUNARODNI DOKUMENTI}

1. Međunarodni pakt o građanskim i političkim pravima (Narodne novine - Međunarodni ugovori, broj 12/1993, 7/1995).

2. Konvencija za zaštitu ljudskih prava i temeljnih sloboda (Narodne novine - Međunarodni ugovori, broj 18/1997, 6/1999 - pročišćeni tekst, 8/1999, 14/2002, 1/2006).

\section{USTAVNI I ZAKONSKI PROPISI}

1. Ustav Republike Hrvatske (Narodne novine, broj 56/1990., 135/1997, 8/1998 - pročišćeni tekst, 113/2000, 124/2000 - pročišćeni tekst, 28/2001, 41/2001 - pročišćeni tekst, 55/2001, 76/2010, $85 / 2010,5 / 2014)$.

2. Zakon o kaznenom postupku (Narodne novine, broj 10/1997, 27/1998, 58/1999, 112/1999, 58/2002, 143/2002, 115/2006).

3. Zakon o kaznenom postupku (Narodne novine, broj 152/2008, 76/2009, 80/2011, 143/2012, 56/2013, 145/2013, 152/2014, 70/2017).

4. Kazneni zakon (Narodne novine, broj 125/2011, 144/2012, 56/2015, 61/2015, 101/2017).

5. Zakon o obveznim odnosima (Narodne novine, broj 35/2005, 41/2008, 125/2011, 78/2015). 
6. Zakon o sudovima (Narodne novine, broj 28/2013, 33/2015, 82/2015, 82/2016).

7. Zakon o državnom odvjetništvu (Narodne novine, broj 76/2009, 153/2009, 116/2010, 145/2010, 57/2011, 130/2011, 72/2013, 148/2013, 33/2015, 82/2015).

8. Prekršajni zakon (Narodne novine, broj 107/2007, 39/2013, 157/2013, 110/2015, 91/2016).

9. Zakon o izvršavanju kazne zatvora (Narodne novine, broj 190/2003 - pročišćeni tekst, 76/2007, 27/2008, 83/2009, 18/2011, 48/2011, 125/2011, 56/2013, 150/2013).

\section{SUDSKE ODLUKE}

1. Odluka Ustavnog suda RH br. U-III-1839/06 od 7. svibnja 2009.

2. Presuda Europskog suda Golder protiv Ujedinjenog Kraljevstva br. 4451/70 od 21. veljače 1975.

3. Presuda Europskog suda X. protiv Ujedinjenog Kraljevstva br. 7215/75 od 5. studenoga 1981.

4. Presuda Europskog suda Ashingdane protiv Ujedinjenog Kraljevstva br. 8225/78 od 28. svibnja 1985.

5. Presuda Europskog suda Brogan i drugi protiv Ujedinjenog Kraljevstva br. 11209/84, 11234/84, 11266/84, 11386/85 od 29. studenoga 1988.

6. Presuda Europskog suda De Geouffre de la Pradelle protiv Francuske br. 129647/87 od 16. prosinca 1992.

7. Presuda Europskog suda Kreuz protiv Poljske br. 28249/95 od 19. lipnja 2001.

8. Presuda Europskog Suda Princ Hans - Adam II. od Lihtneštajna protiv Njemačke br. 42527/98 od 27. srpnja 2001.

9. Presuda Europskog suda Rakevich protiv Rusije br. 58973/00 od 28. listopada 2003.

10. Presuda Europskog suda Stanev protiv Bugarske br. 36760/06 od 17. siječnja, 2012. 


\section{THE RIGHT TO DAMAGES FOR UNJUSTIFIED CONVICTION OR UNFOUNDED ARREST OR DETENTION WITH SPECIAL REFERENCE TO ADMINISTRATIVE PROCEDURE IN EXERCISING THAT RIGHT}

\section{Summary}

According to Croatian law, the procedure for compensation for damage due to unjustified conviction or unfounded arrest or detention is administrative-judicial. The injured party is obliged to refer to the Ministry of Justice before filing a lawsuit against the Republic of Croatia in order to achieve a settlement of damages and compensation. In accordance with the views of the European Court of Human Rights, there are admissible restrictions on the "right of access to a court" guaranteed by Article $6 \S 1$ of the European Convention on Human Rights.

The legal basis of compensation for damage are the rules of international and constitutional law according to which the compensation for damage is subject to public law of an unjustifiably convicted or unfounded arrested or detained person, corresponding to the duty of the state to award compensation. Compensation is a subjective right as it concerns private interests of the injured party but also a public right because it is in the public interest that the innocent citizen is not unjustly convicted or unfounded arrested or detained.

Unlike the Constitution of the Republic of Croatia, which in Article $25 \S 4$ stipulates the right to compensation for damage to a person who was "illegally" deprived of liberty or sentenced, Article 3 of Protocol No. 7 to the 1984 European Convention on Human Rights provides for the right to compensation for wrongful conviction, which is perceived as "unjustified conviction". In its practice, by referring to the concept of "lawfulness" of the deprivation of liberty under Article $5 \S 4$ of the European Convention on Human Rights, the European Court of Human Rights has in fact, in its practice, reimbursed the unjustified arrest and detention (in the sense of the European Convention on Human Rights) of unwarranted arrest and detention.

"Inadmissible" arrest or detention is, in accordance with the provisions of Article 480, a wider term that includes "unjustified" (misdirected under Article 3 of Protocol No. 7 to the European Convention on Human Rights) and "unlawful" arrest or detention.

\section{(c) (i) $(5)$}

This work is licensed under a Creative Commons

Attribution-NonCommercial 4.0 International License.

* $\quad$ Boris Ljubanović, PhD, Full professor, Faculty of Law, Josip Juraj Strossmayer University of Osijek, Stjepana Radića 13, 31000 Osijek, Republic of Croatia. Email address: ljboris@pravos.hr. ORCID: https://orcid org/0000-0003-3995-9991. 
The number of injured party claims for damages to the Croatian administrative body (Ministry of Justice) is significant, and the number of solved applications is considerably smaller. Compensation based on settlement is solely monetary and only because of unjustified arrest or detention. The fees, as a result of the unacceptably large number of unfounded arrests or detentions, are large. The tendency of increase in the number of applications received and paid amounts was curbed in the period from 2013 to 2016, slightly less than the number of claims received and significantly in relation to the amount of money disbursed on the merits.

Keywords: $\quad$ European Court of Human Rights, unjustified conviction, unfounded arrest or detention, damages 